\title{
Synergistic Effects of Incident Diabetes Between Snoring, Family History of Diabetes, and Obesity
}

\section{Diyabet Olgusunun Horlama, Ailede Diyabet Öyküsü ve Obezite Arasındaki Sinerjik Etkileri}

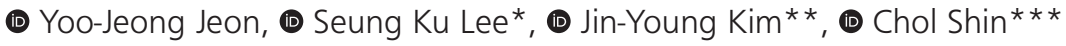

Hanbat National University Faculty of Medicine, Department of Sports and Health Science, Daejeon, Korea

*Institute of Human Genomic Study, College of Medicine, Korea University, Seoul, Republic of Korea

** University of Nevada Faculty of Nursing, Department of Nursing, Las Vegas, USA

***Korea University Ansan Hospital College of Medicine, Department of Pulmonary, Sleep and Critical Care Medicine, Ansan-si, Gyeonggi-do, Republic of Korea

\begin{abstract}
Objective: The general public recognizes the connections between obesity, family history of diabetes (FHD), and diabetes, but remains unaware of synergistic effects that occur due to their combination. In this study, we investigate the synergistic effects of event diabetes between snoring, FHD, and obesity.

Materials and Methods: Study subjects were selected among participants in the Korean Genome and Epidemiology Study AnsanAnsung cohort, an ongoing prospective population-based study. Ansan-Ansung cohort initiated in 2001 and 2002 and has been followed biennially. At baseline, the initial cohort of 10.030 subjects, aged 40 to 69 years. A total of 5.759 participants were included in this study. The relationships between diabetes and snoring, FHD, and obesity were estimated using Cox hazard regression models after adjusting for confounding factors. Snoring, obesity and FHD were significantly associated with diabetes in both males and females after adjustments for covariates. However, males were significantly more likely to have FHD and obesity.

Results: A synergistic effect between these two risk factors showed that being female was associated with the all group after adjustment for covariates. Moreover, there was a high risk of having two risk factors among female patients, while males showed no such tendency. A significant synergistic effect between these three risk factors was seen in females. An exposure group with these three factors had higher diabetes risk than other groups [hazard ratio (HR): 6.27 (95\% confidence interval $(\mathrm{Cl})$ : 2.93-13.41] $\mathrm{p}<0.01$, but this was not seen in males. Especially, premenopausal women was showed significant with FHD, obese, habitual snorer [ $\mathrm{HR}=5.69(95 \% \mathrm{Cl}: 2.31-14.02) \mathrm{p}<0.01]$. But postmenopausal women was showed significant with FHD and habitual snorer both non-obese and obese $[\mathrm{HR}=7.22(95 \% \mathrm{Cl}$ : 1.68-30.99) $\mathrm{p}=0.01$ and $\mathrm{HR}=7.85$ (95\% Cl: $1.88-32.82) \mathrm{p}<0.01$, respectively].
\end{abstract}

Öz

Amaç: Toplum, obezite, ailede diyabet öyküsü (ADÖ) ve diyabet arasındaki bağlantıların farkındadır, ancak bunların kombinasyonundan kaynaklanan sinerjik etkilerin farkında değildir. Bu çalışmada, diyabet olgusunun horlama, ADÖ ve obezite arasındaki sinerjik etkilerini araştırdık.

Gereç ve Yöntem: Çalışmadaki denekler, devam eden, ileriye dönük popülasyon tabanlı bir çalışma olan Kore Genom ve Epidemiyoloji Çalışması Ansan-Ansung kohortundaki katılımcılar arasından seçildi. Ansan-Ansung kohortu 2001 ve 2002'de başlatıldı ve iki yılda bir takip edildi. Başlangıçta, 10,030 denekten oluşan ilk kohortun yaşları 40 ile 69 arasında değişmekteydi. Bu çalışmaya toplam 5,759 katılımcı dahil edilmiştir. Diyabet ve horlama, ADÖ ve obezite arasındaki ilişkiler, karıştırıcı faktörler için uyarlandıktan sonra Cox tehlike regresyon modelleri kullanılarak tahmin edildi. Horlama, obezite ve ADÖ, ortak değişkenler için düzenlemelerden sonra hem erkeklerde hem de kadınlarda diyabet ile anlamlı derecede ilişkili bulundu. Bununla birlikte, erkeklerin ADÖ ve obezite olma olasılığı önemli ölçüde daha yüksekti. Bulgular: Bu iki risk faktörü arasındaki sinerjik bir etki, ortak değişkenler için düzeltme yapıldıktan sonra kadın olmanın tüm grupla ilişkili olduğunu gösterdi. Dahası, kadın hastalarda iki risk faktörüne sahip olma riski yüksekken, erkekler böyle bir eğilim göstermiyordu. Kadınlarda bu üç risk faktörü arasında önemli bir sinerjik etki görülmüştür. Bu üç faktöre sahip bir maruziyet grubu diğer gruplardan daha yüksek diyabet riskine sahipti (tehlike oranı (HR) 6,27 [\%95 güven aralığı (GA): 2,93$13,41] p<0,01$, ancak bu erkeklerde görülmedi. Özellikle premenopozal kadınlarda ADÖ, obezite, habitüel horlama anlamlı idi [HR=5,69 (\%95 GA: 2,31-14,02) $p<0,01]$. Ancak menopoz sonrası hem obez hem de obez olmayan kadınlarda ADÖ ve habitüel horlama ile anlamlı ilişki görüldü $[H R=7,22$ (\%95 GA: 1,68-30,99) $p=0,01$ ve $H R=7,85$ (\%95 GA: $1,88-32,82) \mathrm{p}<0,01$, sırasıyla].

Address for Correspondence/Yazışma Adresi: Prof. MD. Chol Shin, Korea University Ansan Hospital College of Medicine, Department of Pulmonary, Sleep and Critical Care Medicine, Ansan-si, Gyeonggi-do, Republic of Korea

Phone: +82-31-412-5603 E-mail: chol-shin@hanmail.net ORCID-ID: orcid.org/0000-0002-2928-8576

Received/Geliş Tarihi: 19.11.2020 Accepted/Kabul Tarihi: 24.02.2021

${ }^{\circ}$ Copyright 2021 by Turkish Sleep Medicine Society / Journal of Turkish Sleep Medicine published by Galenos Publishing House. 


\begin{abstract}
Conclusion: The combination of obesity, FHD, and habitual snoring was associated with greater susceptibility to diabetes in female patients, while obesity and habitual snoring was associated with greater susceptibility to diabetes in males.

Keywords: Incident diabetes, risk factor, coexistence, snoring, family history, obese
\end{abstract}

Öz

Sonuç: Obezite, ADÖ ve habitüel horlama kombinasyonu kadın hastalarda diyabete yatkınlıkla ilişkiliyken, erkeklerde ise obezite ve habitüel horlama diyabete yatkınlıkla ilişkiliydi.

Anahtar Kelimeler: Diyabet olgusu, risk faktörü, koekzistans, horlama, aile öyküsü, obezite

\section{Introduction}

Diabetes is the most common endocrine disease, caused by the persistence of hyperglycemia due to abnormalities in insulin resistance and beta-cell dysfunction (1). During the past few decades, the prevalence and incidence of diabetes have increased worldwide (2). Diabetes is an important public health issue that is associated with high rates of morbidity and mortality (3).

Diabetes is a multifactorial disease resulting from the complex interplay of polygenic genetic and behavioral factors, and environmental influences (4). Understanding family histories of disease is a simple but clinically powerful tool because family members share similar genetic, cultural, and behavioral traits. Family history of diabetes (FHD) is an important risk factor for developing diabetes, because having one family member with FHD was associated with 2.5-fold increased risk of diabetes. Moreover, biparental FHD conferred even 5.14-fold higher risk (5).

Obesity is increasing rapidly worldwide (6). One consequence of obesity is an increased risk of developing diabetes (7). In previous studies, in a corroborating study, FHD with obesity $30 \leq$ Body Mass index (BMI) was more strongly associated with diabetes (5.7-fold) than either were alone (2.59-fold for BMI and 2.41-fold for FHD) (8). Moreover, the prevalence of impaired glucose tolerance (IGT) and non-insulin dependent diabetes were associated with a 3 -fold increase in FHD in patients with obesity and central obesity (9). As shown in a meta-analysis, obesity is a major contributor to the development of diabetes (10), while reduced weight amplifies health benefits because it leads to improvements in fasting glucose, lipoprotein, and blood pressure. Consequentially, obesity is a modifiable risk factor that can be changed by lifestyle modifications.

Snoring is not only an important signal for sleep-disordered breathing, but it is independently associated with many diseases including abnormalities of insulin secretion, insulin action, hemoglobin $A_{1 C^{\prime}}$ and diabetes (11-15). In addition, a recent meta-analysis reported 1.37 -fold a significant association between diabetes and habitual snoring (16). The effects of obesity and snoring in incident diabetes have been compared based on the presence or absence of these risk factors in males (14). Lack of snoring and obesity were independently associated with incident diabetes (5.1-fold). Moreover, habitual snoring and obesity together result in significantly higher risk of diabetes than either does alone (7.0-fold). Habitual snoring without obesity is not associated with incident diabetes, while habitual snoring is related to increased HbA1c levels in both non-obese men and premenopausal women (1.69-fold and 2.31-fold, respectively) (12). Interestingly, female sex plus habitual snoring have been consistently associated with diabetes (14), while the same relationship is controversial in males (17). Therefore, questions about gender differences remain.

In this study, we examined not only the effects of FHD, obesity, and snoring on incident diabetes, but also any synergistic effects between these risk factors according to sex.

\section{Materials and Methods}

\section{Study Subjects and Populaiton}

Study subjects were selected among participants in the Korean Genome and Epidemiology Study, an ongoing prospective population-based study among the Ansan-Ansung cohort of middle-aged and older adults in Korea (18). The Ansan-Ansung cohort was initiated in 2001 and 2002 and has been followed biennially. At baseline, the initial cohort of 10.030 subjects, aged 40 to 69 years, were randomly recruited from two sites, with 5.012 subjects from the urban community of Ansan (2.518 men and 2.494 women) and 5.018 subjects from the rural community of Ansung (2.240 men and 2.778 women). Data collected from the cohort included questionnaires, anthropometric measurements, blood tests, and clinical examinations by trained interviewers and examiners. Subjects were followed biennially during scheduled site visits for a period of 16 years. For the present study, 1.731 subjects were excluded at baseline [fasting glucose $(n=299), B M I(n=5), T G(n=2), \operatorname{HDL}(n=2), C V D$ $(n=225), B M l<18(n=161)$, and diabetes $(n=1.203)]$. During the 16 year study period, 2.537 out of 8.296 subjects were lost to follow-up due to death $(n=872)$ and follow-up loss $(n=1.665)$. Finally, 5.759 subjects remained eligible for this investigation. This study was approved by the Institutional Review Board of the Korea University Ansan Hospital, and written informed consent was given by all study subjects.

\section{Measurements}

Study subjects completed questionnaires administered by a trained interviewer, which included questions on demographic information, current and past medical conditions, FHD, snoring, and lifestyle. Subjects were asked "Have you ever heard that you snored?", and if so, they asked additional questions about how frequently they snored (sometimes, 1 to 3 time/week; often, 4 to 5 time/week; frequent, 6 to 7 time/week). Snoring status of participants were divided into three different groups: nonsnorer (never), occasional snorer (less than 4 nights a week), and habitual snorer (at least 4 nights a week). The frequency 
of snoring was assessed by an interviewer-administered questionnaire. Assessments of reliability for the snoring questionnaire were performed by test retest. The kappa value for agreement between the two tests was $0.73(11)$. BMI was calculated as weight divided by height squared $\left(\mathrm{kg} / \mathrm{m}^{2}\right)$. World Health Organization (WHO) expert consultation report that BMI cut-off points by race show of difference (19). Additional trigger points for public health action were identified $27.5 \mathrm{~kg} / \mathrm{m}^{2}$ or higher as representing high risk for Asian population. Obesity was defined as a BMI of $27.5 \mathrm{~kg} / \mathrm{m}^{2}$ or more. Positive FHD was defined based on positive parental history of diabetes. Leisuretime physical activity was calculated using questionnaires including questions about type of activity, frequency (times per week), and duration (in minutes). Metabolic equivalents (MET) values were assigned to each sports activity based on the compendium of physical activities. Alcohol consumption was evaluated using questionnaires including kind of drink (beer, wine, hard liquor, and 3 types of traditional drinks, including soju, chungju, and makgeolli), amount, and frequency (times per year). Smoking status was categorized as never, past, and current. Triglyceride, HDL, and fasting glucose levels were measured using an ADVIA 1650 Auto Analyzer (Siemens Medical Solutions, Tarrytown, NY, USA).

\section{Definitions of Diabetes, Hypertension, and Snoring}

We used the diagnostic criteria for diabetes and hypertension proposed by the WHO $(20,21)$. Diabetes was defined as having a fasting plasma glucose concentration $\geq 126 \mathrm{mg} / \mathrm{dL}$, or postprandial 2-h glucose concentration $\geq 200 \mathrm{mg} / \mathrm{dL}$, or current treatment by oral anti-diabetic drugs or insulin. Hypertension was defined as having SBP at least $140 \mathrm{mmHg}$ or DBP at least $90 \mathrm{mmHg}$ or were being treated with antihypertensive medication.

\section{Statistical Analysis}

Baseline characteristics were expressed as means and standard deviations for continuous variables and as percentages for categorical variables. Differences in examinations were determined using generalized linear models and chi-square tests. Multiple comparisons were addressed with Scheffe's post-hoc tests. To estimate the risk of developing diabetes we applied Cox proportional hazards regression models (HRs), $95 \%$ confidence intervals $(\mathrm{Cls})$, and p-values. The potential confounding variables adjusted for in multivariate models are as follows: $\mathrm{FHD}$ (yes, no), obese (BMl<27.5, 27.5 $\leq \mathrm{BMI})$, snoring status (never, occasional, and habitual), age, smoker (never smoking, past smoking, and current smoking), exercise (METs), alcohol consumption (g/day), triglyceride, $\mathrm{HDL}$, fasting glucose, and hypertension (yes, no). Interaction p-values for these risk factors were calculated for every possible combination. The interaction effects for the combination of three risk factors were analyzed using likelihood ratio tests. Risk factors were combined as categories to conduct joint analysis, with the reference being the non-exposure group. A two-tailed $\mathrm{p}<0.05$ was considered statistically significant. All statistical analyses were performed using SAS statistical software (SAS 9.4, SAS Institute, Cary, NC, USA).

\section{Results}

Of the 5.759 individual study subjects, 1.667 (831 of 3.083 women, 836 of 2.676 men) newly developed diabetes during the 16-year follow-up. Table 1 shows the baseline characteristics of the subjects stratified by sex. Males had higher mean values and frequency compared to females as follows: fasting glucose (85.3 \pm 9.3 of men vs. $81.7 \pm 8.2$ of women), BMI (24.4 \pm 2.8 of men vs. $24.9 \pm 3.1$ of women), triglyceride $(174.2 \pm 110.6$ of men vs. $143.8 \pm 80.4$ of women), exercise ( $84.3 \pm 163.9$ of men vs. $75.9 \pm 160.8$ of women), alcohol consumption $(17.0 \pm 26.2$ of men vs. $1.3 \pm 5.6$ of women), hypertension ( $29.5 \%$ of men vs. $26.2 \%$ of women), habitual snorer ( $17.5 \%$ of men vs. $10.8 \%$ of women), past smokers and current $(32.5 \%$ of men vs. $1.1 \%$ of women and $47.4 \%$ of men vs. $3.1 \%$ of women, respectively). In contrast, obese status ( $13.0 \%$ of men vs. $19.5 \%$ of women) and FHD (7.6\% of men vs. $8.6 \%$ of women) were more frequent in females. Age and HDL were higher in females $(50.7 \pm 8.1$ of men vs. $51.5 \pm 8.5$ of women and $43.3 \pm 9.6$ of men vs. $45.6 \pm 9.8$ of women).

Table 2 compares the baseline characteristics among three groups defined by different frequencies of snoring by sex. Fasting blood glucose and triglycerides significantly increased with increasing frequency of snoring in both sexes, and snoring was associated with higher alcohol consumption, obesity, and hypertension than in non-snorers. HDL decreased with increased snoring frequency. Exercise (METs) was increased in men with increasing snoring frequency. Smoking was not associated with snoring status in either females or males.

Table 3 shows the crude HRs and multivariable-adjusted HRs for incident diabetes and snoring status, obesity, and FHD by gender. In the crude model, snoring, obesity, and FHD were significantly associated with incident diabetes in both females and males. After adjustments for covariates, FHD [HR $=1.84$ (95\% Cl: $1.47-2.29) ; \mathrm{p}<0.01)$ for females with positive FHD and $1.29(1.02-1.65 ; p=0.04)$ for males with positive FHD] and obesity [HR=1.34 $(1.14-1.57 ; \mathrm{p}<0.01)$ for obese females and 1.24 (1.03-1.50; $\mathrm{p}=0.02)$ for obese males] were significantly associated with increased risk of 16-year incidence of diabetes in both sexes. However, among females only habitual snorers showed a significant association with incident diabetes [HR=1.25 (1.01-1.56); $p=0.04)$; this was not seen in males.

Table 4 presents the combined effects of snoring status, obesity, and FHD on incident diabetes. We divided groups according to the presence or absence of factors into either four or six groups. The combined non-exposed groups were used as a reference. For patients with the combination of FHD and obesity, multivariate HR for incident diabetes was 1.39 (1.18-1.64; $\mathrm{p}<0.01)$ for negative FHD and being obese, 1.89 (1.47-2.44; $p<0.01$ ) for positive FHD and not being obese, and 2.38 (1.57$3.60 ; p<0.01)$ for positive FHD and being obese, compared to females who were negative for FHD and were not obese. The relationship between positive FHD and obesity showed a different trend in men $[H T=1.27$ (1.05-1.54; $\mathrm{p}=0.01$ for negative FHD and obese, $1.36(1.05-1.76 ; p<0.01)$ for positive FHD and non-obese, $1.24(0.06-2.40 ; p=0.53)$ for positive FHD and obese]. For the combination of FHD and snorer 
Jeon et al.

Joint Interaction Between Snoring, FHD, and Obese

\begin{tabular}{|c|c|c|c|}
\hline & Female & Male & \\
\hline & $n=3.083$ & $n=2.676$ & $\mathbf{p}$ \\
\hline Age (years) & $51.5 \pm 8.5$ & $50.7 \pm 8.1$ & $\mathrm{p}<0.05$ \\
\hline Fasting glucose $(\mathrm{mg} / \mathrm{dL})$ & $81.7 \pm 8.2$ & $85.3 \pm 9.3$ & $\mathrm{p}<0.05$ \\
\hline Body Mass index $\left(\mathrm{kg} / \mathrm{m}^{2}\right)$ & $24.9 \pm 3.1$ & $24.4 \pm 2.8$ & $\mathrm{p}<0.05$ \\
\hline Triglyceride (mg/dL) & $143.8 \pm 80.4$ & $174.2 \pm 110.6$ & $\mathrm{p}<0.05$ \\
\hline $\mathrm{HDL}(\mathrm{mg} / \mathrm{dL})$ & $45.6 \pm 9.8$ & $43.3 \pm 9.6$ & $\mathrm{p}<0.05$ \\
\hline Exercise (MET) & $75.9 \pm 160.8$ & $84.3 \pm 163.9$ & $\mathrm{p}<0.05$ \\
\hline Alcohol consumption (g/day) & $1.3 \pm 5.6$ & $17.0 \pm 26.2$ & $\mathrm{p}<0.05$ \\
\hline Obese $(27.5 \leq \mathrm{BMI})$ & $600(19.5 \%)$ & $348(13.0 \%)$ & $\mathrm{p}<0.05$ \\
\hline Positive FHD & $264(8.6 \%)$ & $203(7.6 \%)$ & $\mathrm{p}<0.05$ \\
\hline Hypertension & $808(26.2 \%)$ & $790(29.5 \%)$ & $\mathrm{p}<0.05$ \\
\hline Snorer & - & - & $\mathrm{p}<0.05$ \\
\hline Non-snorers & $1.386(45.0 \%)$ & $930(34.8 \%)$ & - \\
\hline Occasional snorers & $1.364(44.2 \%)$ & $1.279(47.8 \%)$ & - \\
\hline Habitual snorers & $333(10.8 \%)$ & $467(17.5 \%)$ & - \\
\hline Smoker & - & - & $\mathrm{p}<0.05$ \\
\hline Never smoking & $2.955(95.9 \%)$ & $539(20.1 \%)$ & - \\
\hline Past smoking & $33(1.1 \%)$ & $869(32.5 \%)$ & - \\
\hline Current smoking & $95(3.1 \%)$ & $1.268(47.4 \%)$ & - \\
\hline \multicolumn{4}{|c|}{ BMI: Body Mass index, FHD: Family history of diabetes } \\
\hline
\end{tabular}

status, multivariate HRs for incident diabetes were associated with FHD and snoring status in females [HR=1.28 (1.02-1.61); $\mathrm{p}=0.03$ for negative FHD and habitual snorers, 1.60 (1.112.31; $\mathrm{p}=0.01$ ) for positive FHD and non-snorers, 2.09 (1.53$2.86 ; \mathrm{p}<0.01)$ for positive FHD and occasional snorers, 3.14 $(1.87-5.30 ; \mathrm{p}<0.01)$ for positive FHD and habitual snorers]. In males, incident diabetes was associated with positive FHD only in occasional snorers [1.43 (1.03-1.99; $p=0.03)]$. For the combination of obesity and snoring status, multivariate HRs for incident diabetes were $H R=1.21$ (1.02-1.44; $p=0.03$ ) for non-obese and occasional snorers, $1.45(1.10-1.90 ; \mathrm{p}=0.01)$ for non-obese and habitual snorers, 1.71 (1.31-2.23; $\mathrm{p}<0.01)$ for obese and non-snorers, $1.48(1.18-1.86 ; p<0.01)$ for obese and occasional snorers, and $1.61(1.19-2.17 ; p<0.01)$ for obese and habitual snorers in women. In males, multivariate HR for incident diabetes was 1.35 (1.04-1.76; $p=0.027)$ for obese and occasional snorers. The linear trend $p$-values were significant in females, but not in males except for the multivariate model of snoring and obesity. After adjustments for prominent diabetes risk factors, the interaction $p$-value was only significant in females.

Table 5 shows the effects of 12 combinations of three risk factors including snoring status, FHD, and obesity. After adjustments for other confounding factors, divided groups showed significant associations with non-exposed groups among females, except for obese non-snorers with positive FHD. In particular, an exposure group with all three factors had higher diabetes risk than other groups [HR=6.27 (2.9313.41) $\mathrm{p}<0.01]$. For detail analysis of women, we divided premenopausal and postmenopausal. Premenopausal women was showed significant in positive group of positive of FHD, obese, habitual snorer [ $\mathrm{HR}=5.69$ (95\% Cl: 2.31-14.02) $\mathrm{p}<0.01]$. But, postmenopausal women was showed significant in positive FHD and habitual snorer both non-obese and obese [HR=7.22 (95\% Cl: 1.68-30.99) $\mathrm{p}=0.01$ and $\mathrm{HR}=7.85$ (95\% Cl: 1.88 32.82) $\mathrm{p}<0.01$, respectively]. In men, obesity with occasional snoring in negative FHD, and lack of obesity with occasional snoring in positive FHD were significantly associated with increased risk for diabetes. The linear trend $p$-value and interaction $p$-value was significant in females $(p<0.01$ and $\mathrm{p}<0.01$, respectively) but not in males.

\section{Discussion}

In this prospective cohort study, we explored the synergistic effects between three known risk factors for the onset of diabetes, including snoring status, FHD, and obesity, using a joint model. Findings from the majority of earlier studies have consistently shown significant associations between obesity, FHD, and the combination of both with diabetes. We observed strong associations between incident diabetes, FHD, and obesity in both females and males. Previous studies agreed with the results of the present study by showing that female habitual snorers were more likely to have incident diabetes. The diabetes risk associated with habitual snoring is controversial in males. Our results revealed sex differences in the relationship between habitual snoring and incident diabetes. In a synergistic effect, coexistent habitual snoring may elevate incident diabetes risk in females although obesity and FHD are both main risk factors for developing diabetes. However, the same relationship for male habitual snorers was significant in a crude model, but 
Jeon et al.

Joint Interaction Between Snoring, FHD, and Obese

\begin{tabular}{|c|c|c|c|c|}
\hline & \multicolumn{3}{|l|}{ Snorers } & \multirow[t]{2}{*}{$\mathrm{p}$} \\
\hline & Non & Occasional & Habitual & \\
\hline Female & $n=1.386$ & $\mathrm{n}=1.364$ & $n=333$ & - \\
\hline Age (years) & $50.5 \pm 8.5$ & $51.6 \pm 8.4 \dagger$ & $54.8 \pm 8.4 \ddagger^{*}$ & $<0.01$ \\
\hline Fasting glucose (mg/dL) & $81.1 \pm 8.0$ & $82.0 \pm 8.3 \dagger$ & $82.7 \pm 8.6 \ddagger$ & $<0.01$ \\
\hline Body Mass index $\left(\mathrm{kg} / \mathrm{m}^{2}\right)$ & $24.3 \pm 2.9$ & $25.2 \pm 3.1 \dagger$ & $26.5 \pm 3.2 \ddagger^{*}$ & $<0.01$ \\
\hline Triglyceride $(\mathrm{mg} / \mathrm{dL})$ & $136.9 \pm 76.0$ & $148.1 \pm 84.5 \dagger$ & $155.3 \pm 78.9 \ddagger$ & $<0.01$ \\
\hline $\mathrm{HDL}(\mathrm{mg} / \mathrm{dL})$ & $46.2 \pm 9.9$ & $45.1 \pm 9.7 \dagger$ & $45.0 \pm 9.9$ & $<0.01$ \\
\hline Exercise (MET) & $72.4 \pm 157.8$ & $81.1 \pm 167.3$ & $69.1 \pm 144.7$ & 0.26 \\
\hline Alcohol consumption (g/day) & $1.0 \pm 3.8$ & $1.4 \pm 6.9 \dagger$ & $1.8 \pm 5.6 \ddagger$ & 0.03 \\
\hline Obese (27.5 $\leq \mathrm{BMI})$ & $189(13.6 \%)$ & $288(21.1 \%) \dagger$ & $123(36.9 \%) \ddagger^{*}$ & $<0.01$ \\
\hline Positive FHD & $115(8.3 \%)$ & $122(8.9 \%)$ & $27(8.1 \%)$ & 0.79 \\
\hline Hypertension & $276(19.9 \%)$ & $404(29.6 \%) \dagger$ & $128(38.4 \%) \ddagger^{*}$ & $<0.01$ \\
\hline Smoker & - & - & - & 0.49 \\
\hline Past smoking & $15(1.1 \%)$ & $13(1 \%)$ & $5(1.5 \%)$ & - \\
\hline Current smoking & $39(2.8 \%)$ & $41(3 \%)$ & $15(4.5 \%)$ & - \\
\hline Male & $\mathrm{n}=930$ & $\mathrm{n}=1.279$ & $n=467$ & - \\
\hline Age (years) & $51.7 \pm 8.5$ & $50.2 \pm 8.0 \dagger$ & $50.3 \pm 7.5 \ddagger$ & $<0.01$ \\
\hline Fasting glucose (mg/dL) & $84.0 \pm 9.0$ & $86.0 \pm 9.4 \dagger$ & $86.2 \pm 9.5 \ddagger$ & $<0.01$ \\
\hline Body Mass index $\left(\mathrm{kg} / \mathrm{m}^{2}\right)$ & $23.6 \pm 2.6$ & $24.5 \pm 2.7 \dagger$ & $25.5 \pm 2.8 \ddagger^{*}$ & $<0.01$ \\
\hline Triglyceride $(\mathrm{mg} / \mathrm{dL})$ & $166.5 \pm 104.0$ & $177.0 \pm 116.6 \dagger$ & $181.9 \pm 105.8$ & 0.02 \\
\hline $\mathrm{HDL}(\mathrm{mg} / \mathrm{dL})$ & $44.4 \pm 10.0$ & $43.0 \pm 9.4 \dagger$ & $41.7 \pm 8.6 \ddagger^{*}$ & $<0.01$ \\
\hline Exercise (MET) & $77.9 \pm 154.4$ & $86.8 \pm 166.2$ & $89.9 \pm 175.6$ & 0.32 \\
\hline Alcohol consumption (g/day) & $15.6 \pm 25.9$ & $17.3 \pm 26.1$ & $19.0 \pm 26.7$ & $<0.07$ \\
\hline Obese $(27.5 \leq \mathrm{BMI})$ & $66(7.1 \%)$ & $170(13.3 \%) \dagger$ & $112(24.0 \%) \ddagger^{*}$ & $<0.01$ \\
\hline Positive FHD & $53(5.7 \%)$ & $106(8.3 \%) \dagger$ & $44(9.4 \%) \ddagger$ & 0.02 \\
\hline Hypertension & $243(26.1 \%)$ & $388(30.3 \%) \dagger$ & $159(34.1 \%) \ddagger$ & $<0.01$ \\
\hline Smoker & - & - & - & 0.70 \\
\hline Past smoking & $288(31.0 \%)$ & $429(33.5 \%)$ & $152(32.6 \%)$ & - \\
\hline Current smoking & $457(49.1 \%)$ & $590(46.1 \%)$ & $221(47.3 \%)$ & - \\
\hline
\end{tabular}

the significance disappeared after adjustments for confounding effects. However, the coexistence of obesity with FHD in nonsnorers and occasional snorers was found to be significant. The interaction terms were not significant in female patients with FHD obesity, and snoring, possibly due to a lack of statistical power rather than actual lack of effect. Moreover, Synergistic effects in premenopausal and postmenopausal women was showed difference results. Postmenopausal women was showed significant in positive group FHD and habitual snorer both nonobese and obese.

Diabetes is a chronic metabolic disease with multifactorial pathogenesis, which is characterized mainly by insulin resistance and beta cell dysfunction (4). Insulin resistance is a pathologic condition in which insulin fails to elicit responses in the liver, skeletal muscle, and adipose tissue, which are peripheral insulin target tissues. Beta cell dysfunction occurs when beta cells in the pancreas fail to produce normal amounts of insulin. Of course, this process is affected by many factors such as hyperglycemia, lipotoxicity, inflammation, adipokines, oxidative stress, insulin resistance, autoimmunity, islet amyloid, and incretins. Beta cell dysfunction impairs glucose homeostasis, leading to diabetes (22).

FHD, obesity, and snoring is important risk factors for diabetes. Familial aggregation studies are important for the identification of genetic determinants of disease. The contribution of underlying maternal and paternal influences to diabetes is well studied $(5,23)$. Offspring of parents with diabetes have higher fasting glucose, abnormal glucose tolerance (NGT), and prevalence of diabetes. In addition, family history was strongly associated with risk of diabetes after adjustments for prominent diabetes risk factors such as physical activity, BMI, waist circumference, and multi-SNP genetic risk score (5). Recently, a susceptibility 
Jeon et al.

Joint Interaction Between Snoring, FHD, and Obese

\begin{tabular}{|c|c|c|c|}
\hline & & Crude & Multivariate adjusted \\
\hline & & [HR $(95 \% \mathrm{Cl}) \mathrm{p}$-value] & [HR $(95 \% \mathrm{Cl}) \mathrm{p}$-value] \\
\hline \multirow{2}{*}{ FHD } & Negative FHD & Reference & Reference \\
\hline & Positive FHD & $1.43(1.15-1.77)<0.01$ & $1.84(1.47-2.29)<0.01$ \\
\hline \multirow{3}{*}{ Snorers } & Non-snorers & Reference & Reference \\
\hline & Occasional snorers & $1.33(1.15-1.55)<0.01$ & $1.11(0.96-1.29) 0.16$ \\
\hline & Habitual snorers & $1.80(1.46-2.22)<0.01$ & $1.25(1.01-1.56) 0.04$ \\
\hline \multicolumn{4}{|l|}{ Male } \\
\hline FHD & Negative FHD & Reference & Reference \\
\hline \multirow{3}{*}{ Snorers } & Non-snorers & Reference & Reference \\
\hline & Occasional snorers & $1.17(1.00-1.37) 0.05$ & $1.03(0.88-1.20) 0.76$ \\
\hline & Habitual snorers & $1.28(1.05-1.55) 0.01$ & $1.01(0.83-1.24) 0.92$ \\
\hline \multicolumn{4}{|c|}{$\begin{array}{l}\text { The potential confounding variables adjusted in the multivariate models are as follows: } \mathrm{FHD} \text { (yes, no), obese (BMl<27.5 kg/m2, } 27.5 \leq \mathrm{BMl}) \text {, snoring status (never, } \\
\text { occasional, and habitual), age, smoker (never smoking, past smoking, and current smoking), exercise (METs), alcohol consumption (g/day), triglyceride, HDL, fasting } \\
\text { glucose, and hypertension (yes, no). }\end{array}$} \\
\hline \multicolumn{4}{|c|}{ BMI: Body Mass index, FHD: Family history of diabetes, MET: Metabolic equivalents, $\mathrm{Cl}$ : Confidence interval } \\
\hline
\end{tabular}

\begin{tabular}{|c|c|c|c|c|c|}
\hline & & \multicolumn{2}{|l|}{ Female } & \multicolumn{2}{|l|}{ Male } \\
\hline & & $\begin{array}{l}\text { Crude } \\
\text { [HR }(95 \% \mathrm{Cl}) \text { p-value) }\end{array}$ & $\begin{array}{l}\text { Multivariate } \\
{[\mathrm{HR}(95 \% \mathrm{Cl}) \mathrm{p} \text {-value }]}\end{array}$ & $\begin{array}{l}\text { Crude } \\
{[\mathrm{HR}(95 \% \mathrm{Cl}) \mathrm{p} \text {-value] }}\end{array}$ & $\begin{array}{l}\text { Multivariate } \\
{[\mathrm{HR}(95 \% \mathrm{Cl}) \mathrm{p} \text {-value] }}\end{array}$ \\
\hline \multirow[t]{2}{*}{ Negative FHD } & Non-obese & Reference & Reference & Reference & Reference \\
\hline & Obese & $1.99(1.70-2.34)<0.01$ & $1.39(1.18-1.64)<0.01$ & $1.70(1.42-2.04)<0.01$ & $1.27(1.05-1.54) 0.01$ \\
\hline Positive FHD & Non-obese & $1.51(1.18-1.94)<0.01$ & $1.89(1.47-2.44)<0.01$ & $1.45(1.12-1.86)<0.01$ & $1.36(1.05-1.76) 0.02$ \\
\hline \multicolumn{2}{|l|}{ P-value for trend } & $<0.01$ & $<0.01$ & $<0.01$ & 0.02 \\
\hline Non-snorers & Negative FHD & Reference & Reference & Reference & Reference \\
\hline Occasional snorers & & $1.32(1.13-1.54)<0.01$ & $1.12(0.96-1.31) 0.16$ & $1.15(0.98-1.35) 0.09$ & $1.04(0.88-1.23) 0.63$ \\
\hline Habitual snorers & & $1.75(1.40-2.18)<0.01$ & $1.28(1.02-1.61) 0.03$ & $1.33(1.08-1.62)<0.01$ & $1.11(0.90-1.36) 0.33$ \\
\hline Non-snorers & Positive FHD & $1.31(0.91-1.88) 0.15$ & $1.60(1.11-2.31) 0.01$ & $1.39(0.87-2.22) 0.16$ & $1.58(0.99-2.54) 0.06$ \\
\hline Non-snorers & Non-obese & Reference & Reference & Reference & Reference \\
\hline Occasional snorers & & $1.34(1.13-1.59)<0.01$ & $1.21(1.02-1.44) 0.03$ & $1.10(0.93-1.30) 0.28$ & $1.00(0.85-1.19) 0.99$ \\
\hline Habitual snorers & & $1.73(1.32-2.26)<0.01$ & $1.45(1.10-1.90)<0.01$ & $1.21(0.97-1.51) 0.10$ & $1.03(0.82-1.29) 0.81$ \\
\hline Non-snorers & Obese & $2.21(1.70-2.88)<0.01$ & $1.71(1.31-2.23)<0.01$ & $1.39(0.91-2.11) 0.13$ & $1.07(0.70-1.63) 0.77$ \\
\hline Occasional snorers & & $2.29(1.84-2.86)<0.01$ & $1.48(1.18-1.86)<0.01$ & $1.95(1.52-2.52)<0.01$ & 1.35 (1.04-1.76) 0.03 \\
\hline Habitual snorers & & $2.71(2.02-3.63)<0.01$ & $1.61(1.19-2.17)<0.01$ & $1.64(1.21-2.24)<0.01$ & $1.18(0.86-1.63) 0.30$ \\
\hline \multicolumn{2}{|l|}{ P-value for trend } & $<0.01$ & $<0.01$ & $<0.01$ & 0.04 \\
\hline \multicolumn{6}{|c|}{$\begin{array}{l}\text { The potential confounding variables adjusted in the multivariate models are as follows: } \mathrm{FHD} \text { (yes, no), obese (BMI<27.5, } 27.5 \leq \mathrm{BMI}) \text {, snoring status (never, occasional, } \\
\text { and habitual), age, smoker (never smoking, past smoking, and current smoking), exercise (METs), alcohol consumption (g/day), triglyceride, HDL, fasting glucose, and } \\
\text { hypertension (yes, no) }\end{array}$} \\
\hline
\end{tabular}


Jeon et al.

Joint Interaction Between Snoring, FHD, and Obese

\begin{tabular}{|c|c|c|c|}
\hline \multirow[b]{2}{*}{ Female } & & \multicolumn{2}{|c|}{ Multivariate [HR $(95 \% \mathrm{Cl}) \mathrm{p}$-value] } \\
\hline & & Negative FHD & Positive FHD \\
\hline Non-snorers & Non-obese & Reference & $1.89(1.27-2.81)<0.01$ \\
\hline Occasional snorers & & $1.20(1.00-1.44) 0.05$ & $2.28(1.58-3.29)<0.01$ \\
\hline Habitual snorers & & $1.43(1.07-1.91) 0.02$ & $2.59(1.27-5.25)<0.01$ \\
\hline Non-snorers & Obese & $1.84(1.39-2.42)<0.01$ & $1.34(0.50-3.62) 0.56$ \\
\hline Occasional snorers & & $1.47(1.15-1.87)<0.01$ & $2.67(1.52-4.71)<0.01$ \\
\hline Habitual snorers & & $1.50(1.09-2.07) 0.01$ & $6.27(2.93-13.41)<0.01$ \\
\hline \multicolumn{2}{|c|}{ P-value for interaction } & \multicolumn{2}{|l|}{$\mathrm{p}<0.01$} \\
\hline \multicolumn{2}{|l|}{ Premenopause } & Negative FHD & Positive FHD \\
\hline Non-snorers & Non-obese & Reference & $2.03(1.32-3.14)<0.01$ \\
\hline Occasional snorers & & $1.23(1.00-1.52) 0.05$ & $2.36(1.56-3.57)<0.01$ \\
\hline Habitual snorers & & $1.30(0.92-1.84) 0.13$ & $2.17(0.96-4.92) 0.06$ \\
\hline Non-snorers & Obese & $1.99(1.46-2.72)<0.01$ & $1.94(0.72-5.25) 0.19$ \\
\hline Occasional snorers & & $1.42(1.07-1.89) 0.02$ & $2.48(1.34-4.59)<0.01$ \\
\hline Habitual snorers & & $1.62(1.11-2.37) 0.01$ & $5.69(2.31-14.02)<0.01$ \\
\hline \multicolumn{2}{|c|}{ P-value for interaction } & \multicolumn{2}{|l|}{$\mathrm{p}<0.01$} \\
\hline \multicolumn{2}{|l|}{ Postmenopause } & Negative FHD & Positive FHD \\
\hline Non-snorers & Non-obese & Reference & $1.47(0.53-4.11) 0.46$ \\
\hline Occasional snorers & & $1.11(0.76-1.63) 0.59$ & $1.85(0.81-4.25) 0.15$ \\
\hline Habitual snorers & & $1.72(1.00-2.97) 0.05$ & $7.22(1.68-30.99) 0.01$ \\
\hline Non-snorers & Obese & $1.36(0.72-2.53) 0.34$ & - \\
\hline Occasional snorers & & $1.63(1.02-2.62) 0.04$ & $4.99(1.15-21.58) 0.03$ \\
\hline Habitual snorers & & $1.27(0.70-2.31) 0.44$ & $7.85(1.88-32.82)<0.01$ \\
\hline \multicolumn{2}{|c|}{ P-value for interaction } & \multicolumn{2}{|l|}{$p<0.01$} \\
\hline \multicolumn{2}{|l|}{ Male } & Negative FHD & Positive FHD \\
\hline Non-snorers & Non-obese & Reference & $1.68(1.03-2.72) 0.04$ \\
\hline Occasional snorers & & $1.00(0.84-1.19) 0.98$ & $1.45(1.03-2.05) 0.04$ \\
\hline Habitual snorers & & $1.08(0.86-1.37) 0.50$ & $0.87(0.45-1.70) 0.69$ \\
\hline Non-snorers & Obese & $1.12(0.72-1.72) 0.62$ & $0.87(0.12-6.24) 0.89$ \\
\hline Occasional snorers & & $1.39(1.06-1.83) 0.02$ & $1.60(0.65-3.91) 0.31$ \\
\hline Habitual snorers & & $1.24(0.89-1.72) 0.20$ & $1.04(0.33-3.27) 0.95$ \\
\hline \multicolumn{2}{|c|}{ P-value for interaction } & \multicolumn{2}{|l|}{$p=0.614$} \\
\hline \multicolumn{4}{|c|}{$\begin{array}{l}\text { The potential confounding variables adjusted in the multivariate models are as follows: } \mathrm{FHD}(\mathrm{yes}, \mathrm{no}) \text {, obese }\left(\mathrm{BMl}<27.5 \mathrm{~kg} / \mathrm{m}^{2}, 27.5 \leq \mathrm{BMl}\right) \text {, snoring status (never, } \\
\text { occasional, and habitual), age, smoker (never smoking, past smoking, and current smoking), exercise (METs), alcohol consumption (g/day), triglyceride, HDL, fastin } \\
\text { glucose, and hypertension (yes, no). }\end{array}$} \\
\hline \multicolumn{4}{|c|}{ BMI: Body Mass index, MET: Metabolic equivalents, FHD: Family history of diabetes, Cl: Confidence interval, HR: Hazard ratio } \\
\hline
\end{tabular}

locus identified during a GWAS meta-analysis for diabetes was found to overlap with loci involved in adipocytokine signaling, cell cycle regulation, and CREBBP-related transcription, all of which are involved in the pathogenesis of diabetes including insulin resistance and beta cell function (24). Consequently, FHD is a better predictor than any other risk factor for diabetes because it reflects both environmental and genetic factors.

Obesity is an important accelerating risk factor in the pathogenesis of diabetes through secretion of non-esterified fatty acids (NEFAs), adipokines (leptin and adiponectin), and inflammatory cytokines (TNF alpha, IL-6, and IL-1 beta) to form adipose tissue, which is chronically increased in obesity (25). Increased NEFA concentrations are common in obesity and diabetes and cause insulin resistance by inhibition of glucose transport and/or phosphorylation with a subsequent reduction of glucose oxidation and glycogenesis in muscle. Consequentially, high NEFA concentrations are not only thought to have a causal relationship with insulin resistance and glucose intolerance, but also to be a risk factor for transition from IGT to diabetes $(26,27)$. Adipokines such as leptin and adiponectin are 
predominantly made by adipocytes. Derived TNF alpha, IL-6, and IL-1 beta from adipose tissue, which induces macrophage activation and infiltration that enhance the production of these cytokines (28). These results indicate that cytokines activate the JNK and NF-kB signals, which results in low grade inflammation and promotes the generation of ROS and nitrogen. Therefore, increases in cytokine concentration could be responsible for increased oxidative stress. In addition, high circulating NEFA levels influence overproduction of ROS via beta-oxidative phosphorylation in mitochondria. ROS exert negative regulation on insulin signaling, inducing the development of insulin resistance, which is a risk factor for diabetes (22).

In previous studies, habitual snoring was independently associated with many diseases including abnormalities of insulin secretion and insulin action, and the prevalence and incidence of diabetes $(8,9,14-17,29)$. Snoring is produced by vibrations of the upper airway walls due to partial disturbance of the upper airway, which is an important signature of sleep-disordered breathing (SDB). Impairment to the exchange of gases in the respiratory system by SDB increases oxygen desaturation. Eventually, this causes hypoxia and hypercapnia (30). Increased hypoxia and hypercapnia lead to sympathetic nervous activity, in which catecholamine, epinephrine and norepinephrine, and cortisol are released by triggering the physiologic stress response $(31,32)$. SDB is associated with increased inflammatory markers such as TNF-alpha, IL-6, hsCRP, which could be secondary to the combined interactions of obesity and hyperglycemia (33). As a result, the systemic effect of sympathetic neural hyperactivity, increased catecholamine and inflammatory markers impair glucose homeostasis by promoting glucose production through the activation of glycogenolysis and gluconeogenesis, and inhibit insulin secretion and insulin mediated glucose uptake by skeletal muscles $(34,35)$. This in turn causes an increase of circulating insulin and increased risk of insulin resistance, which may result in diabetes (36).

The menopause condition is associated with several physiological change that may impact women heath outcome. Hormonal change in postmenopausal women lead to increased fat mass and abdominal fat, and decreased lean body mass comparison of premenopausal women, which have been linked to insulin sensitivity and glucose metabolism (37).

Because diabetes is a multifactorial disease resulting from complex interplays of many risk factors, it is very important to understand the interaction between risk factors. In previous studies, the coexistence of obesity and FHD in females showed an increased combined effect on NGT, IGT, and diabetes $(8,9,29)$. Consequently, the effect of combined obesity, FHD, and snoring on the development of diabetes seems to be due to amplification of inflammatory cytokine signals and ROS production.

The general public recognizes the connections between obesity, FHD, habitual snoring, and diabetes, but remains unaware of synergistic effects that occur due to their combination. Our results suggest that the coexistence of obesity, FHD, and habitual snoring increases susceptibility to diabetes in females. But coexistence of these risk factors was not found in males.

\section{Study Limitations}

Limitation of this study was small sample size because groups were stratified. Future research will require larger sample sizes. In addition, the effects of the coexistence of obesity, FHD, and snoring on cardiovascular diseases, morbidity, and mortality should also be studied.

\section{Conclusion}

Obesity, FHD, and snoring are easily accessible without special screening, the results of this study will increase the understanding of diabetes and potentially contribute to the prevention of diabetes by promoting voluntary lifestyle changes.

\section{Acknowledgments}

This research was supported by the Bio \& Medical Technology Development Program of the National Research Foundation of Korea (NRF) funded by the Ministry of Science, ICT \& Future Planning (no. 2015M3A9B6027142), by research funding (nos. 2001-347-6111-221, 2002-347-6111-221, 2003-3476111-221, 2004-E71001-00, 2005-E71001-00, 2006-E7100600, 2006-E71005-00, 2007-E71003-00， 2007-E71001-00, 2008-E71005-00, 2008-E71001-00, 2009-E71007-00, 2009E71002-00, 2010-E71004-00, 2010-E71001-00, 2011-E7100800, 2011-E71004-00, 2012-E71008-00, 2012-E71005-00, 2013-E71007-00, 2013-E71005-00, 2014-E71005-00, 2014E71003-00, 2015-E71002-00, 2015-P71001-00, 2016-E7100200, 2016-E71003-00, 2017-E71001-00, 2017-E71002-00, 2018-E7101-00, and 2018-E7102-00) from the Korea Centers for Disease Control and Prevention, and by a Korea University Grant.

\section{Ethics}

Ethics Committee Approval: This study was approved by the Institutional Review Board of the Korea University Ansan Hospital (approval date: 2021.01.26).

Informed Consent: Written informed consent was given by all study subjects.

Peer-review: Internally peer-reviewed.

\section{Authorship Contributions}

Concept: S.K.L., Y.J.J., Design: C.S., Data Collection or Processing: S.K.L., Y.J.J., J.Y.K., Analysis or Interpretation: C.S., Writing: S.K.L., Y.J.J., J.Y.K., C.S.

Conflict of Interest: No conflict of interest was declared by the authors.

Financial Disclosure: The authors declared that this study received no financial support.

\section{References}

1. Kahn SE, Cooper ME, Del Prato S. Pathophysiology and treatment of type 2 diabetes: perspectives on the past, present, and future. Lancet 2014;383:1068-83.

2. NCD Risk Factor Collaboration (NCD-RisC). Worldwide trends in diabetes since 1980: a pooled analysis of 751 population-based studies with 4.4 million participants. Lancet 2016;387:1513-30.

3. Garcia MJ, McNamara PM, Gordon T, Kannel WB. Morbidity and mortality in diabetics in the Framingham population. Sixteen year follow-up study. Diabetes 1974;23:105-11. 
4. Hansen T. Type 2 diabetes mellitus--a multifactorial disease. Ann Univ Mariae Curie Sklodowska Med 2002;57:544-9.

5. InterAct C, Scott RA, Langenberg C, Sharp SJ, Franks PW, Rolandsson $O$, Drogan D, van der Schouw YT, Ekelund U, Kerrison ND, Ardanaz E, Arriola L, Balkau B, Barricarte A, Barroso I, Bendinelli B, Beulens JW, Boeing $\mathrm{H}$, de Lauzon-Guillain B, Deloukas P, Fagherazzi G, Gonzalez C, Griffin SJ, Groop LC, Halkjaer J, Huerta JM, Kaaks R, Khaw KT, Krogh V, Nilsson PM, Norat T, Overvad K, Panico S, Rodriguez-Suarez L, Romaguera D, Romieu I, Sacerdote C, Sanchez MJ, Spijkerman AM, Teucher B, Tjonneland A, Tumino R, van der AD, Wark PA, McCarthy MI, Riboli E, Wareham NJ. The link between family history and risk of type 2 diabetes is not explained by anthropometric, lifestyle or genetic risk factors: the EPIC-InterAct study. Diabetologia 2013;56:60-9.

6. Prentice AM. The emerging epidemic of obesity in developing countries. Int J Epidemiol 2006;35:93-9.

7. Hruby A, Hu FB. The epidemiology of obesity: a big picture. Pharmacoeconomics 2015;33:673-89.

8. Chen Y, Rennie DC, Dosman JA. Synergy of BMI and family history on diabetes: the Humboldt Study. Public Health Nutr 2010;13:461-5.

9. Mykkanen L, Laakso M, Uusitupa M, Pyorala K. Prevalence of diabetes and impaired glucose tolerance in elderly subjects and their association with obesity and family history of diabetes. Diabetes Care 1990;13:1099-105.

10. Anderson JW, Kendall CW, Jenkins DJ. Importance of weight management in type 2 diabetes: review with meta-analysis of clinical studies. J Am Coll Nutr 2003;22:331-9.

11. Shin C, Kim J, Kim J, Lee S, Shim J, In K, Kang K, Yoo S, Cho N, Kimm $\mathrm{K}$, Joo S. Association of habitual snoring with glucose and insulin metabolism in nonobese Korean adult men. Am J Respir Crit Care Med 2005; 171:287-91.

12. Joo S, Lee S, Choi HA, Kim J, Kim E, Kimm K, Kim J, Shin C. Habitual snoring is associated with elevated hemoglobin A1c levels in nonobese middle-aged adults. J Sleep Res 2006;15:437-44.

13. Al-Delaimy WK, Manson JE, Willett WC, Stampfer MJ, Hu FB. Snoring as a risk factor for type II diabetes mellitus: a prospective study. Am J Epidemiol 2002;155:387-93.

14. Elmasry A, Janson C, Lindberg E, Gislason T, Tageldin MA, Boman G. The role of habitual snoring and obesity in the development of diabetes: a 10-year follow-up study in a male population. J Intern Med 2000;248:13-20.

15. Wei Y, Zheng B, Fan J, Lv J, Guo Y, Bian Z, Du H, Yang L, Chen Y, Chen J, Zhong X, Chen J, Chen Z, Yu C, Li L, China Kadoorie Biobank Collaborative Group. Habitual snoring, adiposity measures and risk of type 2 diabetes in 0.5 million Chinese adults: a 10-year cohort. BMJ Open Diabetes Res Care 2020;8:e001015.

16. Xiong $\mathrm{X}$, Zhong A, Xu H, Wang C. Association between selfreported habitual snoring and diabetes mellitus: a systemic review and meta-analysis. J Diabetes Res 2016;2016:1958981. doi: 10.1155/2016/1958981.

17. Enright PL, Newman AB, Wahl PW, Manolio TA, Haponik EF, Boyle PJ. Prevalence and correlates of snoring and observed apneas in 5,201 older adults. Sleep 1996;19:531-8.

18. Kim Y, Han BG, KoGES Group. Cohort profile: the Korean genome and epidemiology study (koges) consortium. Int I Epidemiol 2017;46:e20.

19. WHO Expert Consultation. Appropriate body-mass index for Asian populations and its implications for policy and intervention strategies. Lancet 2004;363:157-63.

20. Chalmers ], MacMahon S, Mancia G, Whitworth J, Beilin L, Hansson L, Neal B, Rodgers A, Ni Mhurchu C, Clark T. 1999 World Health Organization-International Society of Hypertension Guidelines for the management of hypertension. Guidelines sub-committee of the
World Health Organization. Clin Exp Hypertens 1999;21:1009-60.

21. Alberti KG, Zimmet PZ. Definition, diagnosis and classification of diabetes mellitus and its complications. Part 1: diagnosis and classification of diabetes mellitus provisional report of a $\mathrm{WHO}$ consultation. Diabet Med 1998; 15:539-53.

22. Kahn SE, Hull RL, Utzschneider KM. Mechanisms linking obesity to insulin resistance and type 2 diabetes. Nature 2006;444:840-6.

23. Harrison TA, Hindorff LA, Kim H, Wines RC, Bowen DJ, McGrath BB, Edwards KL. Family history of diabetes as a potential public health tool. Am J Prev Med 2003;24:152-9.

24. Morris AP, Voight BF, Teslovich TM, Ferreira T, Segre AV, Steinthorsdottir $\mathrm{V}$, Strawbridge RJ, Khan $\mathrm{H}$, Grallert $\mathrm{H}$, Mahajan A, Prokopenko I, Kang HM, Dina C, Esko T, Fraser RM, Kanoni S, Kumar A, Lagou V, Langenberg C, Luan J, Lindgren CM, Muller-Nurasyid M, Pechlivanis S, Rayner NW, Scott LJ, Wiltshire S, Yengo L, Kinnunen L, Rossin EJ, Raychaudhuri S, Johnson AD, Dimas AS, Loos RJ, Vedantam S, Chen $\mathrm{H}_{\text {, }}$ Florez JC, Fox C, Liu CT, Rybin D, Couper DJ, Kao WH, Li M, Cornelis $M C$, Kraft $P$, Sun $Q$, van Dam RM, Stringham HM, Chines PS, Fischer $\mathrm{K}$, Fontanillas $\mathrm{P}$, Holmen OL, Hunt SE, Jackson AU, Kong A, Lawrence R, Meyer J, Perry JR, Platou CG, Potter S, Rehnberg E, Robertson N, Sivapalaratnam S, Stancakova A, Stirrups K, Thorleifsson G, Tikkanen E, Wood AR, Almgren P, Atalay M, Benediktsson R, Bonnycastle LL, Burtt N, Carey J, Charpentier G, Crenshaw AT, Doney AS, Dorkhan M, Edkins S, Emilsson V, Eury E, Forsen T, Gertow K, Gigante B, Grant GB, Groves C], Guiducci C, Herder C, Hreidarsson AB, Hui J, James A, Jonsson A, Rathmann W, Klopp N, Kravic J, Krjutskov K, Langford C, Leander K, Lindholm E, Lobbens S, Mannisto S, Mirza G, Muhleisen TW, Musk B, Parkin M, Rallidis L, Saramies J, Sennblad B, Shah S, Sigurethsson G, Silveira A, Steinbach G, Thorand B, Trakalo J, Veglia F, Wennauer R, Winckler W, Zabaneh D, Campbell H, van Duijn C, Uitterlinden AG, Hofman A, Sijbrands E, Abecasis GR, Owen KR, Zeggini E, Trip MD, Forouhi NG, Syvanen AC, Eriksson JG, Peltonen L, Nothen MM, Balkau B, Palmer CN, Lyssenko V, Tuomi T, Isomaa B, Hunter DJ, Qi L, Wellcome Trust Case Control Consortium, MetaAnalyses of Glucose and Insulin-related traits Consortium (MAGIC) Investigators, Genetic Investigation of ANthropometric Traits (GIANT) Consortium, Asian Genetic Epidemiology Network-Type 2 Diabetes (AGEN-T2D) Consortium; South Asian Type 2 Diabetes (SAT2D) Consortium, Shuldiner AR, Roden M, Barroso I, Wilsgaard T, Beilby J, Hovingh K, Price JF, Wilson JF, Rauramaa R, Lakka TA, Lind L, Dedoussis G, Njolstad I, Pedersen NL, Khaw KT, Wareham NJ, Keinanen-Kiukaanniemi SM, Saaristo TE, Korpi-Hyovalti E, Saltevo J, Laakso M, Kuusisto J, Metspalu A, Collins FS, Mohlke KL, Bergman RN, Tuomilehto J, Boehm BO, Gieger C, Hveem K, Cauchi S, Froguel P, Baldassarre D, Tremoli E, Humphries SE, Saleheen D, Danesh J, Ingelsson E, Ripatti S, Salomaa V, Erbel R, Jockel KH, Moebus S, Peters A, Illig T, de Faire U, Hamsten A, Morris AD, Donnelly PJ, Frayling TM, Hattersley AT, Boerwinkle E, Melander O, Kathiresan S, Nilsson PM, Deloukas P, Thorsteinsdottir U, Groop LC, Stefansson K, Hu F, Pankow JS, Dupuis J, Meigs JB, Altshuler D, Boehnke M, McCarthy MI, DIAbetes Genetics Replication And Meta-analysis (DIAGRAM) Consortium. Large-scale association analysis provides insights into the genetic architecture and pathophysiology of type 2 diabetes. Nat Genet 2012;44:981-90.

25. Roden M, Price TB, Perseghin G, Petersen KF, Rothman DL, Cline GW, Shulman GI. Mechanism of free fatty acid-induced insulin resistance in humans. J Clin Invest 1996;97:2859-65.

26. Pankow JS, Duncan BB, Schmidt MI, Ballantyne CM, Couper DJ, Hoogeveen RC, Golden SH, Atherosclerosis Risk in Communities Study. Fasting plasma free fatty acids and risk of type 2 diabetes: the atherosclerosis risk in communities study. Diabetes Care 2004;27:77-82.

27. Charles MA, Eschwege E, Thibult N, Claude JR, Warnet JM, Rosselin GE, Girard J, Balkau B. The role of non-esterified fatty acids in the deterioration of glucose tolerance in Caucasian subjects: results of the Paris prospective study. Diabetologia 1997;40:1101-6. 
Jeon et al.

Joint Interaction Between Snoring, FHD, and Obese

28. Weisberg SP, McCann D, Desai M, Rosenbaum M, Leibel RL, Ferrante AW, Jr. Obesity is associated with macrophage accumulation in adipose tissue. J Clin Invest 2003;112:1796-808.

29. Ning F, Pang Z, Laatikainen T, Gao W, Wang S, Zhang L, Tuomilehto J, Qiao Q, Qingdao 2006 Diabetes Survey and FINRISK 2002 Study. Joint effect of family history of diabetes with obesity on prevalence of type 2 diabetes mellitus among Chinese and Finnish men and women. Can J Diabetes 2013;37:65-71.

30. Hoffstein V, Chaban R, Cole P, Rubinstein I. Snoring and upper airway properties. Chest 1988;94:87-9.

31. Somers VK, Dyken ME, Clary MP, Abboud FM. Sympathetic neural mechanisms in obstructive sleep apnea. J Clin Invest 1995;96:1897-904.

32. Somers VK, Mark AL, Abboud FM. Sympathetic activation by hypoxia and hypercapnia--implications for sleep apnea. Clin Exp Hypertens A 1988;10(Suppl 1):413-22.
33. Ciftci TU, Kokturk O, Bukan N, Bilgihan A. The relationship between serum cytokine levels with obesity and obstructive sleep apnea syndrome. Cytokine 2004;28:87-91.

34. Marshall S, Garvey WT, Traxinger RR. New insights into the metabolic regulation of insulin action and insulin resistance: role of glucose and amino acids. FASEB J 1991;5:3031-6.

35. Rizza RA, Cryer PE, Haymond MW, Gerich JE. Adrenergic mechanisms of catecholamine action on glucose homeostasis in man. Metabolism 1980;29:1155-63.

36. Flaa A, Aksnes TA, Kjeldsen SE, Eide I, Rostrup M. Increased sympathetic reactivity may predict insulin resistance: an 18-year follow-up study. Metabolism 2008;57:1422-7.

37. Szmuilowicz ED, Stuenkel CA, Seely EW. Influence of menopause on diabetes and diabetes risk. Nat Rev Endocrinol 2009;5:553-8. 